\title{
STRUKTUR UPACARA ADAT PERKAWINAN PERANAKAN TIONGHOA DI TELUKNAGA TANGERANG
}

\author{
Feby Yoana Siregar \\ Fakultas Ilmu Budaya \\ Universitas Sumatera Utara
}

\begin{abstract}
This study aims to determine the structure of traditional Chinese crossbreed in Indonesia wedding ceremonies. The research data is the result of informant interview. The method used in this research is descriptive qualitative method by using ceremonial theory and acculturation theory. The author chose this title because it is one of the unique traditions in Indonesia. This tradition is a blend of Chinese culture, Betawi and Sunda. Cio Tou is one of the traditional wedding tradition procession in Teluknaga Tangerang. The tradition of Cio Tou exists only in the tradition of the Chinese crossbreed customs in Teluknaga Tangerang. The results obtained in this research are 7 stages of traditional ceremony in Chinese crossbreed marriage that is the selection of soul mate, applying, dowry, youth evening, Cio Tou tradition, wedding reception, and custom after marriage.
\end{abstract}

Keywords: Cio Tou, Chinese crossbreed, Customary Wedding

\section{PENDAHULUAN}

Upacara perkawinan merupakan hal penting dalam budaya Tionghoa. Upacara perkawinan masyarakat Tionghoa dilaksanakan sesuai dengan aturan agama yang dipeluk oleh kedua mempelai dan disahkan dalam upacara adat yang disebut Cio Tou.

Perkawinan bagi masyarakat Tionghoa adalah merupakan salah satu bentuk xiao (bakti kepada orangtua dan kepada leluhur) yaitu untuk melanjutkan keturunan dan pemujaan kepada leluhur). Tujuan perkawinan bukan hanya untuk kebahagiaan kedua mempelai saja, tetapi juga untuk kesejahteraan dua keluarga yang disatukan dalam perkawinan tersebut. Syarat perkawinan yang terpenting harus diperhatikan adalah larangan untuk kawin dengan Tionghoa dari satu marga. Calon mempelai yang berasal dari satu marga dianggap memiliki hubungan darah dan hal ini akan berdampak buruk para keturunan yang dilahirkan. Dalam budaya 
Tionghoa tidak diharapkan perkawinan antara laki-laki dan perempuan kerabat dekat dengan status kekerabatan perempuan yang lebih tua, misalnya perkawinan lakilaki dengan saudara atau sepupu ibu atau ayahnya.

Salah satu keragaman budaya masyarakat Tionghoa di Indonesia terlihat pada tradisi Cio Tou dalam perkawinan adat peranakan Tionghoa di Tangerang. Tradisi ini merupakan perpaduan adat budaya Betawi, Sunda dan Tionghoa. Tradisi Cio Tou hampir ditinggalkan generasi muda karena dianggap kuno, menghabiskan banyak waktu dan uang. Namun sekarang tradisi tersebut mulai diminati lagi oleh masyarakat setempat karena mereka menganggap tradisi Cio Tou adalah salah satu tradisi yang unik.

Berdasarkan uraian diatas, penulis tertarik untuk meneliti adat perkawinan masyarakat Tionghoa di Kecamatan Teluknaga-Tangerang, karena disana terdapat masyarakat peranakan Tionghoa dan hanya di Teluknaga-Tangerang yang memiliki tradisi Cio Tou dalam perkawinan adatnya. Sekitar 11.452 jiwa warga Indonesia keturunan Tionghoa yang bermukim di Tangerang (Rekapitulasi

Kependudukan Laporan Kabupaten Tangerang, 2011).

Untuk mendekskripsikan serta mengkaji struktur upacara perkawinan pada penelitian ini, penulis menggunakan teori yang dikemukakan oleh Koentjaraningrat (1984:190) upacara ritual adalah sistem aktifasi atau rangkaian tindakan yang ditata oleh adat atau hukum yang berlaku dalam masyarakat yang berhubungan dengan bagaimana macam peristiwa tetap yang biasanya terjadi pada masyarakat yang bersangkutan. Upacara ritual memiliki aturan dan tatacara yang telah ditentukan oleh masyarakat atau kelompok pencipta ritual tersebut, sehingga masing-masing ritual mempunyai perbedaan, baik dalam hal pelaksanaan ataupun perlengkapannya. Mengenai akulturasiKoentjaraningrat (2005:155) mengatakan bahwa akulturasi merupakan istilah yang dalam antropologi mempunyai beberapa makna (Acculturation, atau Culture Contact). Ini semua menyangkut konsep mengenai proses sosial yang timbul apabila sekelompok manusia dengan suatu kebudayaan tertentu dihadapkan pada unsur-unsur dari suatu kebudayaan asing sehingga unsur-unsur asing itu lambat laun diterima dan diolah kedalam kebudayaan sendiri, tanpa menyebabkan hilangnya kepribadian kebudayaan itu.

\section{METODE PENELITIAN}

Penelitian ini menggunakan metode deskriptif kualitatif. Bogdan dan Taylor (1992: 21-22) menjelaskan bahwa penelitian kualitatif adalah salah satu prosedur penelitian yang menghasilkan data deskriptif berupa ujaran atau tulisan dan perilaku orang-orang yang diamati. Penelitian dilakukan di Kecamatan Teluknaga Kota Tangerang. Peneliti fokus pada daerah tersebut, karena pada daerah 
tersebut sebagian besar penduduknya adalah Peranakan Tionghoa. Dalam penelitian kualitatif ini, peneliti menjadi instrumen penelitian karena pada penelitian kualitatif mengharuskan peneliti terjun langsung sebagai instrumen dalam penelitian. Peneliti kualitatif sebagai human instrument berfungsi menetapkan fokus penelitian, memilih informan sebagai sumber data, melakukan pengumpulan data, menilai kualitas data, analisis data, menafsirkan data dan membuat kesimpulan atas temuannya. Dengan demikian, jelas diketahui bahwa penelitian yang dilakukan ini merupakan penelitian kualitatif.

Sementara itu, data yang dianalisis dalam penelitian ini hasil wawancara dari informan. Data tersebut didapat dari pernikahan antara Ferdinand dan Yati Gunawijaya di Teluknaga Tangerang pada tanggal 4 Januari 2017. Sugiyono (2013:4) menyatakan pada penelitian kualitatif, pengumpulan data dilakukan pada natural setting (setting alamiah) dan teknik pengumpulan data lebih banyak pada observasi, dan wawancara. Teknik pengumpulan data yang digunakan dalam penelitian ini adalah metode observasi dan interview.

Setelah data terkumpul, data kemudian dianalisis secara desktiptif kualitatif dengan menggunakan teknik analisis data Miles, Huberman dan Saldana (2014) yang terdiri dari tiga tahap: (1) memilah data (data condensation), (2) menyajikan data (data display), dan (3) menarik kesimpulan atau verifikasi (conclusion drawing and verification). Tahap-tahap dianalisis data sesuai dengan teori Miles, Huberman dan Saldana (2014) adalah sebagai berikut:

1) Memilah data (data condensation) Dalam tahap memilah data, meringkas dan memadatkan data terdapat beberapa tahap sebagai berikut:

1. Selecting yaitu proses menyeleksi hasil wawancara dan rekaman pada prosesi tradisi Cio Tao.

2. Focusing yaitu proses memfokuskan analisis data pada hasil wawancara dan rekaman. Dalam penelitian ini peneliti memfokuskan analisis data terhadap hasil wawancara dari informan.

3. Simplifying yaitu menyederhanakan data. Data dari setiap runtutan prosesi tradisi Cio Tao yang didapatkan baik berupa hasil wawancara maupun gambar disederhanakan dengan tujuan untuk mempermudah analisis data.

4. Abstracting dan trasnsforming yaitu mencatat seluruh hasil temuan. Setelah keseluruhan data dianalisis, peneliti membuat temuan dari keseluruhan data yang sudah diteliti untuk memperjelas hasil penelitian yang sudah dilakukan.

2) Penyajian data (data display)

Penyajian data adalah sebuah pengorganisasian, penyatuan dari informasi yang memungkinkan penyimpulan dan aksi. Penyajian data membantu dalam memahami 
apa yang terjadi dan untuk melakukan sesuatu, termasuk analisis yang lebih mendalam atau mengambil aksi berdasarkan pemahaman. Dalam menyajikan data terdapat beberapa tahapan, yaitu:

1. Mendeskripsikan setiap struktur upacara adat perkawinan Peranakan Tionghoa di TeluknagaTangerang. Deskripsi tersebut dilakukan secara alamiah tanpa ada menambah atau mengurang runtunan tradisi tersebut.

2. Menyajikan temuan dari hasil analisis struktur upacara adat perkawinan Peranakan Tionghoa di Teluknaga Tangerang.

\section{3) Kesimpulan: Gambar/Verifikasi}

Simpulan disusun sebagai tahapan terakhir dari penelitian. Kesimpulan terdiri atas struktur apa saja yang terdapat di dalam tradisi Cio Tao disertai temuan secara detil.

\section{HASIL DAN ANALISIS}

Penduduk etnis Tionghoa yang tinggal di daerah Teluknaga, Tangerang, banyak yang sampai kini masih memegang teguh tradisi budaya Tionghoa. Tentunya tradisi budaya yang dijalankan oleh mereka sudah mengalami akulturasi dengan budaya asli setempat, khususnya budaya Betawi. Salah satu bentuk tradisi yang masih dijalankan oleh masyarakat Tionghoa Teluknaga adalah tata upacara tradisi perkawinan tradisional. Perkawinan tradisional yang biasa diadakan memiliki beberapa tahapan dan ritual, yaitu:

\section{Pemilihan Jodoh}

Ada beberapa hal yang menjadi pertimbangan umum para orangtua peranakan Tionghoa di Teluknaga dalam menyeleksi calon menantu. Yang pertama, ia harus berasal dari keluarga baik-baik. Mereka menghindari calon yang diketahui masih dalam garis keturunanya. Kepribadian dan sikap orangtuanya juga diperhatikan karena takut mempengaruhi perkembangan jiwa anaknya.

Keperawanan seorang gadis adalah hal yang sangat dijunjung. Masih banyak orang tua yang berpandangan kolot mengenai hal ini. Mereka kurang suka dengan gadis yang diketahui sering berpergian dengan teman-teman prianya. Walaupun belum tentu ia melakukan perbuatan yang tidak terpuji. Orang tua seperti itu umumnya lebih menyukai gadis yang senang tinggal dirumah, sebab kecil kemungkinan untuk melakukan hal-hal tidak terpuji, dan ia juga sudah terlatih melakukan pekerjaan rumah tangga, sehingga bisa memberikan perhatian yang lebih besar kepada suami dan anakanaknya kelak.

Meskipun kini perkawinan perkawinan yang dilandasi rasa saling tertarik dan saling mencintai sudah menjadi kebiasaan, namun baik generasi muda maupun tua tetap percaya bahwa perkawinan yang dilangsungkan tanpa restu orang tua tidak akan bahagia. Karena 
itu dalam prosedur pemilihan jodoh, ada dua pola yang biasa digunakan, yakni pola orang tua memilih, anak menyetujui dan pola anak memilih, orang tua menyetujui.

Perkawinan yang didasari pola pertama sering disebut dengan perkawinan yang dijodohkan orang tua, atau kawin jodoh. Karena pasangan yang menjalaninya dipertemukan atas uasaha orang tua. Namun kawin jodoh ini tidak bersifat paksaan karena orang tua hanya membantu mencarikan pasangan dan keputusan diambil berdasarkan keputusan orang tua dan anaknya.

Dalam pola kedua orang tua lebih banyak bersifat mengarahkan dan mengawasi. Menurut pengakuan para orang tua yang anaknya melakukan pola seperti ini, pengawasan dan pengarahan ini tetap perlu dilakukan untuk menghindari kemungkinan buruk yang mungkin terjadi. Mereka tidak ingin anak mereka salah memilih jodoh, dipermainkan orang atau terjerumus dalam hal-hal negative yan dapat merusak masa depan mereka sendiri. Jadi dalam pola ini, walaupun si anak diberi kesempatan dan kebebasan memilih sendiri pasangannya mereka tetap harus berkonsultasi dengan orang tuanya.

\section{Melamar}

Tahapan melamar akan ditempuh setelah ditemukan calon yang cocok, baik dalam pola perjodohan pertama maupun kedua selalu pihak laki-laki yang bertindak sebagai pelamar. Tetapi dalam keadaan tertentu orang tua pihak perempuan juga dapat mendesak pihak laki-laki untuk melamar anak mereka. Misalnya, karena kekasih anak mereka tak kunjung memberi isyarat akan menikahi dia, padalah mereka sudah lama bersama.

Pada hari yang telah disepakati untuk melangsungkan kegiatan melamar, orang tua pihak laki-laki berkunjung kerumah pihak perempuan dan didampingi oleh keluarga dan kerabat. Kehadiran para pendamping juga diperlukan untuk menyempurnakan pembicaraan dalam tahap ini, terutama bila orang tua yang bersangkutan belum berpengalaman dalam hal ini.

Setelah pembicaraan selesai orang tua pihak laki-laki menyerahkan angpao berisi sejumlah uang kepada orang tua pihak perempuan,. Pemberian angpao oleh orang tua pihak laki-laki ke pihak perempuan mengandung makna, orang tua pihak laki-laki menyampaikan terima kasih kepada orang tua pihak perempuan atas kesediaan menerima kedatangan mereka.

\section{Mas Kawin}

Menjelang hari pernikahan, keluarga pihak laki-laki mengantarkan mas kawin kerumah calon mempelai perempuan. Kegiatan ini disebut dengan serah uang. Disebut serah uang karena mas kawin yang diserahkan biasanya sejumlah uang. Penyerahan uang tersebut dipandang ibarat pemberian panjar dalam transaksi dagang, yakni bahwa transaksi tersebut jadi dilakukan. Kegiatan mengantar mas 
kawin sebenarnya merupakan salah satu bagian dari rangkaian upacara Sangjit (送日). Namun sering kali peranakan Tionghoa di daerah ini menganggap keduanya identik. Upacara sangjit dilakukan setelah tahapan melamar.Pelaksanaan upacara tersebut biasanya telah disepakati oleh kedua belah pihak keluarga. Orang tua mempelai lakilaki berkunjung ke rumah pihak perempuan dengan keluarga dan kerabat dekatnya. Sedangkan calon mempelai laki-laki sendiri tetap tinggal dirumah.

Keberangkatan rombongan keluarga calon mempelai laki-laki biasanya diawali dengan pembakaran petasan di halaman depan rumahnya. Menurut kepercayaan masyarakat peranakan Tionghoa, pembakaran petasan ini bertujuan menakut-nakuti dan mengusir para jin, setan dan roh-roh jahat yang mencoba mengganggu jalannya acara.

Jumlah pembawa antaran kawin harus berjumlah genap, sebab bilangan genap melambangkan kesempurnaan dan kestabilan. Seseorang akan lebih sempurna bila ada pasangan hidup. Antaran kawin dan nampan untuk membawanya dihias dengan kertas berwarna merah dan pita merah. Warna tersebut melambangkan suka cita, kehidupan, kekayaan, dan suasana yang bebas dari roh jahat. Penggunaan hiasan serba merah mengisyaratkan harapan dan doa agar kegiatan yang berlangsung diliputi suasana cerah- ceria, dan bebas dari gangguan atau kekacauan.

Uang yang diserahkan sebagai mas kawin ada dua macam. Masingmasing dimasukkan kedalan angpao khusus yang lebih mewah dan ukurannya lebih besar dari biasanya. Yang jumlahnya kecil disebut juga uang susu, sedangkan yang jumlahnya besar disebut juga dengan uang sangjit atau uang pesta.

Pemberian uang susu melambangkan pernyataan terima kasih dang anti rugi bagi orangtua calon mempelai perempuan yang telah tulus membesarkan putrinya, terutama ibunya yang menyusui. Sedangkan uang sangjit atau uang pesta adalah sumbangan keluarga calon mempelai laki-laki untuk resepsi atau pesta yang akan diselenggarakan. Uang sangjit biasanya diterima seluruhnya oleh pihak perempuan. Besar dan wujud mas kawin yang diberikan pihak lakilaki tergantung pada kemampuan dan ke ikhlasan mereka. Pihak perempuan harus menerima berapapun atau apapun yang diserahkan pihak keluarga laki-laki, jadi tidak ada tawar menawar dalam hal ini.

Antaran mas kawin lainnya yang dibawa juga mengandung simbol tertentu dan juga disediakan dalam jumlah genap. Biasanya benda-benda tersebut berupa:

1. Dua pasang lilin merah yang panjang dan besar, yang sering disebut juga dengan liong cek atau longzhu (龙烛). Biasanya dibadan 
lilin tersebut terdapat gambar naga, binatang mistik dalam mitologi Cina dianggap mempunyai pengaruh yang baik bagi kehidupan manusia.Binatang ini merupakan lambang kekuatan, kebaikan, perlindungan, kewaspadaan, dan pada masa lampau menjadi symbol kekaisaran Cina.

2. Dua botol arak. Menurut informan minuman ini melambangkan simbol kesehatan, sebab biasanya digunakan untuk mencegah atau mengobati penyakit.

3. Dua belas macam kue yang disusun menjadi satu tumpukan. Maknanya adalah melambangkan suka duka dalam rumah tangga yang harus dijalani dan dinikmati bersama.

4. Perlengkapan dan perhiasan wanita, seperti pakaian, sepatu, sandal, jam tangan, kalung, antinganting, gelang dan kosmetik.

Benda-benda antaran diletakkan di meja abu keluarga calon mempelai perempuan, berdekatan dengan benda- benda yang disediakan keluarga calon mempelai perempuan untuk calon mempelai laki-laki.

Calon mempelai perempuan bersama kedua orangtuanya membakar hio dan berdoa didepan meja abu. Setelah itu orangtuanya mengambil salah satu nampan berisi barang dari keluarga calon mempelai laki-laki dan memutarkannya diatas kepala calon mempelai perempuan. Kemudian calon mempelai perempuan soja kepada leluhur dan kepada kedua orangtuanya. Kegiatan tersebut dilakukan sebagai penghormatan kepada leluhur.

Ada beberapa ritual yang akan dilangsungkan beberapa hari sebelum hari pernikahan. Salah satunya adalah anceng, yaitu upacara membersihkan ranjang dan kamar pengantin dari roh-roh jahat. Peranakan Tionghoa di daerah ini biasanya menyebutnya dengan upacara selamatan tempat tidur. Upacara anceng biasanya dilakukan seminggu sebelum hari perkawinan. Upacara ini hanya dilakukan di rumah calon pengantin laki-laki, sebab setelah upacara dan pesta perkawinan, mempelai perempan akan tinggal dirumah mempelai lakilaki. Alas tidur, Kain penutup ranjang, dan sarung bantal dipasang oleh kedua orang tua mempelai lakilaki sambil mengulum sepotong gula batu.

\section{Malam Muda-Mudi}

Malam muda-mudi diadakan bagi kaum muda. Pada malam tersebut calon mempelai perempuan dan lakilaki menjamu teman-teman mereka. Ada pasangan yang menyelenggarakannya secara terpisah dan ada juga yang secara bersama di salah satu rumah pasangan calon pengantin. Acara ini biasanya diselenggarakan tiga hari atau empat hari sebelum hari perkawinan. Malam tersebut dianggap sebagai malam terakhir bagi kedua calon mempelai untuk menikmati kesenangan sebagai pemuda dan pemudi lajang bersama teman-teman. 
Kesibukan pada hari perkawinan sudah dimulai sejak pagi hari. Setelah mandi dan keramas, calon mempelai duduk sambil mempersiapkan diri menghadapi rangkaian kegiatan pada hari tersebut. Tukang rias telah tiba beberapa jam sebelum waktu yang ditentukan untuk melakukan upacara perkawinan guna untuk menyiapkan dan menata perlengkapan upacara. Perlengkapan upacara penulis kelompokkan dalm dua golongan utama, yaitu peralatan upacara serta pakaian dan aksesoris pengantin.

\section{Tradisi Cio Tou}

Upacara pertama dari rangkaian upacara pada hari perkawinan adalah Cio Tou yakni upacara pemurnian atau inisiasi memasuki masa dewasa. Dikalangan peranakan Tionghoa di Tangerang umunya, istilah Cio Tou ini juga berarti perkawinan adat peranakan Tionghoa. Jadi, bila seseorang sudah dikatakan kawin Cio Tou, tetapi belum kawin surat, artinya ia sudah menjalani perkawinan menurut adat peranakan Cina, namun perkawinannya belum di sahkan oleh negara. Sebelum upacara dimulai, kedua orang tua kedua mempelai menghadap meja samkai dan soja tiga kali kepada leluhur. Kemudian menyalakan dua batang lilin yang diberikan juru rias dan soja tiga kali kepada leluhur. Setelah itu kedua orangtua mempelai menjemput mempelai perempuan dikamarnya untuk melaksanakan upacara Cio Tou. Sang mempelai dengan digandeng kedua orang tuanya, masuk kedalam nyiru lebar bergambar taikek yang telah disediakan diruang tengah. Sebelum duduk dikursi yang berada diatas nyiru, ia soja kepada kedua orang tuanya kemudian mereka soja kepada leluhur.

Pakaian mempelai perempuan untuk upacara ini ialah rok kun hijau dengan baju putih. Tidak banyak perhiasan yang dipakainya. Rambutnya hanya diurai kemudian dahinya ditempelkan kertas berwarna merah berbentuk segitiga kecil. Jika kertas tersebut tidak bisa menempel di dahinya berarti mempelai perempuan sudah tidak suci lagi. Sedangkan pakaian yang digunakan mempelai laki-laki adalah baju dan celana longgar berwarna putih. Nyiru dengan gambar taikek ditengahnya dianggap merupakan representasi dari dunia. Kemudian dengan melangkah masuk kedalamnya secara simbolis berarti mempelai sudah memasuki dunia baru.

Setelah itu, juru rias mulai merias pengantin. Sebelum dirias, rambut mempelai perempuan disisir adiknya tiga kali. Jika mempelai tidak punya adik, dapat digantikan oleh kerabatnya. Kemudian juru rias menyanggul rambut mempelai perempuan tepat diatasa ubunubunnya. Sementara memepelai perempuan dirias, orang tua dan kerabat mempelai memberikan uang pelita yang biasanya dibungkus dengan angpao. Setelah selesai dirias, orang tua memakaikan baju pengantin lengkap, yakni baju merah panjang dan aksesori lainnya. 
Upacara selanjutnya disebut dengan paijiu ( 拜酒: bai jiu ) atau upacara minum arak. Kedua orang tua duduk kemudian kedua mempelai membumbengkuk mempersembahkan dua buah mangkuk kecil berisi arak yang diletakkan diatas nampan. Mereka secara bergantian memberikan semangkuk arak. Setelah upacara ini kemudian kedua mempelai memakan dua belas macam makanan. Makanan yang disediakan tidak dibatasi jenisnya. Dihadapan mempelai diletakkan masing-masing mangkuk, sepasang sumpit dan secangkir teh. Upacara ini diawali dengan membakar lilin. Kemudian ibu dari mempelai mengambil sedikit nasi dan menyuapinya. Sebelum memasukkan ke dalam mulut, nasi di cecah ke air gula di piring kecil dan ke setiap makanan yang tersedia didalam dua belas mangkuk. Sedangkan sang ayah menyminumkannya secangkir teh. Penyuapan ini dilakukan tiga kali. Dalam upacara ini mempelai diingatkan bahwa bila dahulu ia tidak susah payah mencari makan sebab orang tuanya yang telah menyediakannya. Mulai sekarang ia harus berjuang untuk setiap butir nasi bagi rumah tangganya. Dua belas mangkok melambangkan jumlah bulan dalam satu tahun. Makna mencecahkan nasi ke air gula dan ke dua belas macam makanan adalah agar kedua mempelai sepanjang kehidupannya selalu mendapat rezeki serta pengalaman hidup yang manis dan menyenangkan seperti rasa gula. Khusus untuk mempelai wanita, setelah itu orang tuanya mengikatkan sebuah kantong merah berisi kitab di perutnya, lalu menyelubungi kepalanya dengan selubung atau kain hijau. Setelah itu, pasangan mempelai memasuki kamar pengantin untuk melakukan serangkaian upacara. Pada saat mempelai berjalan menuju kamar, mereka ditaburi dengan beras kuning, bunga, dan beberapa uang logam oleh seorang wanita paruh baya. Seorang wanita paruh baya yang lainnya memayungi kedua mempelai dari belakang. Anak- anak kecil memperebutkan uang logam yang bertebaran di lantai. Upacara ini disebut dengan sawer.

Upacara sawer merupakan pengaruh budaya lokal yaitu budaya Sunda. Warna kuning dari beras tadi diibaratkan emas, lambang kekayaan, dan kemuliaan. Menurut sumber yang penulis baca, uang logam juga lambang kekayaan, bunga-bunga melambangkan keharuman. Penaburan benda-benda tersebut mengandung arti tertentu, yakni agar mereka kelak menjadi orang-orang terhormat, yang memiliki nama harum, selalu berlimpah rezeki, dan suka menolong orang lain.

Sedangkan makna dari payung tersebut adalah agar mereka senantiasa terlindungi dan selalu waspada. Upacara pertama yang dilakukan dikamar pengantin disebut dengan upacara cimpang. Diawali dengan soja kedua pengantin, kemudian mempelai laki-laki membuka selubung hijau wajah 
istrinya. Selubung itu perlahan-lahan dibuka dengan cara digulung. Setelah itu dia melepaskan kantong merah yang berisi kitab dari perut istrinya, dan mencabut beberapa kembang goyang yang ada di atas kepala wanita itu.

Kemudian mempelai wanita membuka kancing baju paling atas suaminya, setelah itu mengancingkannya kembali. Menurut sumber yang penulis dapatkan, menjelaskan bahwa itu merupakan simbol dari adegan malam pengantin. Karena itu hanya bersifat simbolik biasanya upacara ini hanya disaksikan oleh juru rias dan juru foto. Setelah upacara dikamar pengantin, kemudian kedua mempelai kembali keruang tengah dan melakukan prosesi selanjutnya yaitu makan onde. Kedua mempelai saling menyuapkan onde berwarna merah dan putih. Panganan ini menurut salah seorang informan adalah lambang kesuburan dan diharapkan agar pasangan dikaruniai anak dan cucu.

Kedua mempelai kemudian saling meminumkan air teh. Setelah itu mereka saling menyuapkan makanan lain. Ketika mereka makan, pada saat itu juga juru rias menyebutkan makna dari makanan yang dimakan kedua mempelai. Selanjutnya adalah upacara minum teh, atau biasa disebut dengan teh pai. Upacara ini dilakukan mempelai laki-laki terhadap orang tu dan saudarasaudara istrinya yang telah menikah, begitu juga sebaliknya. Upacara minum teh memiliki arti sabagai perkenalan mempelai dengan keluarga pasangannya dan sebagai tanda diterimanya sebagai menantu. Mereka yang dijamu duduk berdampingan dengan pasangannya. Yang mendapat giliran pertama adalah orang tua mempelai. Secara simbolis mereka minum teh dari cangkir yang ada diatas nampan yang dipersembahkan mempelai kepada mereka. Sebagai ucapan terima kasih, mereka meletakkan angpao diatas nampan tersebut.

Setelah melaksanakan semua upacara tersebut, kedua mempelai berkeliling mengucapkan terima kasih kepada para tamu dan kepada orangorang yang telah membantu melaksanakan acara, seperti juru rias, juru masak, kerabat dekat dan sebagainya. Selama upacara itu berlangsung diiringi oleh sekelompok musik Gambang Kromong. Gambang Kromong adalah sejenis orkes yang memadukan gamelan dengan alat-alat musik Tionghoa, seperti sukong, tehyan, dan kongahyan. Sebutan gambang kromong diambil dari nama dua buah alat perkusi, yaitu gambang dan kromong. Awal mula terbentuknya orkes gambang kromong tidak lepas dari seorang pemimpin komunitas Tionghoa yang diangkat Belanda (kapitan Cina) bernama Nie Hoe Kong (masa jabatan 1736-1740).

\section{Resepsi Pernikahan}

Pada saat resepsi pernikahan biasanya saudara laki-laki kedua mempelai menyambut tamu yang 
hadir di depan pintu. Biasanya hadiah dari para tamu diletakkan disebuah meja dekat pintu masuk. Sebagian besar tamu memberikan angpao yang dimasukkan kedalam kaleng atau kotak khusus yang diberikan lubang. Upacara dan pesta perkawinan dapat dilangsungkan dirumah mempelai ataupun di gedung atau ruangan yang disewa. Salah satu tempat khusus yang disewakan untuk perkawinan tradisional peranakan Tionghoa di daerah ini dikenal dengan rumah kawin dari atau rumah pesta. Struktur dasar bangunan ini terdiri tiga ruangan utama, yakni ruang utama terletak di paling depan. ruang kedua di tengah bangunan dan ruang ketiga di bagian belakang bangunan. Ayah mempelai menjamu para tamu pria diruangan terdepan. Tamu- tamu istimewa seperti ketua adat, kepala desa, ataupun pejabat duduk bersama beliau di sebuah meja panjang yang merupakan meja kehormatan. Beberapa bangku panjang ditempatkan disekeliling ruangan ini. Panggung untuk penyanyi dan pemusik disediakan disebelah kiri ruangan depan.

Para wanita dan ibu-ibu serta saudara perempuan lainnya berada diruang tengah dan belakang. Pada kesempatan ini penulis sangat tertarik karena para ibu-ibu sedang bermain judi. Mereka seolah-olah terbenam dalam kegiatan tersebut, melupakan sejenak tentang kesibukan sehari-hari. Perjudian yang dilaksanakan pada pesta perkawinan ini sebenarnya merupakan salah satu bentuk pengumpulan dana untuk menutupi pengeluaran pesta. Jadi, setiap orang yang menang harus menyisihkan sebagian uangnya dan memberikannya kepada tuan rumah sebagai imbalan fasilitas judi yang disediakan. Namun sekarang sudah mulai di tinggalkan karena sebagian dari mereka lebih memilih mengumpulkan uang dan memberikannya ke tuan rumah dari pada bermain judi.

\section{Adat setelah pernikahan}

Setelah selesai upacara adat dan resepsi pernikan, mempelai perempuan tinggal dirumah suaminya. Setelah tinggal selama satu sampai tiga bulan, ia pulang kerumah orang tuanya bersama suaminya. Mereka membawa buahbuahan, kue ataupun makanan lainnya sebagai buah tangan. Pada hari kedatangan mereka kerumah orang tua mempelai perempuan, biasanya diadakan makan bersama orang tua dan saudara-saudaranya. Biasanya mereka menetap untuk beberapa hari disana.

Pola menetap sesudah menikah pada prinsipnya adalah pola patrilokal. Anak laki-laki yang telah menikah membawa istri dan anakanaknya tinggal di tempat orang tuanya, biasanya serumah ataupun tidak serumah tetapi dalam satu halaman dengan rumah orang tuanya. Menurut informan, biasanya yang menjalani pola ini adalah anak laki-laki tertua.

Sekarang telah banyak anak lakilaki yang menempuh pola menetap neolokal. Tempat tinggal baru 
mereka tidak hanya di daerah Tangerang dan sekitarnya, karena saat ini banyak dari mereka yang pergi merantau.

Pola menetap lainnya adalah pola matrilokal. Dalam hal ini pengantin memilih tinggal di sekitar kediaman keluarga perempuan, seperti pada masyarakat Tionghoa di Cina. Di dalam keluarga biasanya paling tidak, ada tiga generasi yang makan dari satu dapur. Beberapa keluarga yang penulis kenal, mereka mengaku tidak memiliki keinginan membentuk keluarga ideal ala masyarakat Tionghoa tradisional, yakni keluarga terdiri dari lima generasi yang hidup bersama dalam satu atap, menggunakan dana yang sama, makan dari satu dapur, di pimpin oleh satu kepala keluarga yakni lakilaki tertua dari generasi paling senior. Adanya tiga sampai empat generasi dalam sebuah keluarga semata-mata merupakan suatu kenyataan sosial yang di timbulkan oleh pola menetap patrilokal dan matrilokal.

\section{SIMPULAN}

Peranakan Tionghoa. Terdiri atas 7 tahapan, yaitu: pemilihan jodoh, melamar, mas kawin, malam muda mudi, tradisi cio tou, resepsi pernikahan, adat setelah menikah. Perkawinan tradisional peranakan Tionghoa di daerah tersebut telah dipengaruhi oleh unsur budaya penduduk setempat, yaitu: etnis Sunda dan Betawi. Contohnya: pakaian pengantin, tradisi sawer, dan orkes gambang kromong yang memeriahkan acara perkawinan tersebut.

Hubungan yang baik antara masyarakat Tionghoa peranakan dengan penduduk asli setempat di Teluknaga telah berlangsung sejak lama. Dalam melangsungkan upacara perkawinan, sikap saling menghormati dan menghargai antar umat beragama terlihat jelas. Misalnya: pada acara berlangsung, untuk menghormati para tamu yang beragama Islam tidak dihidangkan makanan yang mengandung babi dan minuman yang beralkohol.

\section{REFERENSI}

Bogdan, R. \& Steven, T. (1992). Pengantar Metode Kualitatif. Surabaya: Usaha Nasional

Iwan, Santosa. (2012). Peranakan Tionghoa di Nusantara, Jakarta: Kompas.

Kaplan, David, R.A. (2001) Teori Budaya, Yogyakarta: Puataka Pelajar

Koentjaraningrat. (2005). Pengantar Ilmu Antropologi. Jakarta: PT. Rineka Cipta

Koentjaraningrat. (1987). Sejarah Teori Antropologi. Jakarta: UIPress.

Lan, N. J. (2013) Peradaban Tionghoa Selayang Pandang. Jakarta: Kepustakaan Populer Gramedia (KPG). 
Miles, Huberman, \& Saldana. (2014).

Qualitative Data Analysis.

London: SAGE Publications.

Sugiono. 2009. Metode Penelitian

Bisnis

(Pendekatan

Kuantitatif, Kualitatif, dan

R\&D) Bandung: Alfabeta. 